\title{
MAP SHOWING OUTCROPS OF GRANITIC ROCKS AND SILICIC SHALLOW-INTRUSIVE ROCKS, BASIN AND RANGE PROVINCE, NEW MEXICO
}

\author{
Compiled by F. Allan Hills and K. A. Sargent
}

\section{INTRODUCTION}

This map report is one of a series of geologic and hydrologic maps covering all or parts of the states within the Basin and Range province of the western United States. The map reports contain information on subjects that characterize the geohydrology of the province, including the ground-water hydrology, ground-water quality, surface distribution of selected rock types, tectonic conditions, areal geophysics, Pleistocene lakes and marshes, and mineral and energy resources. This work is part of the U.S. Geological Survey's program for geologic and hydrologic evalutaion of the Basin and Range province to identify potentially suitable regions for further study relative to storage of high-level nuclear waste (Bedinger, sargent, and Reed, 1984).

This map report on the granitic rocks and silicic shallowintrusive rocks of New Mexico was prepared from published geologic maps and reports utilizing the project guidelines of Sargent and Bedinger (1984). The map shows outcrops of mostly plutonic granitic rocks, but also of fine-grained and partly glassy, silicic, shallow-intrusive rocks. The outcrops have been grouped into numbered county areas, which are outlined on the map. The Description of Map Units includes the geologic, and if available, radiometric ages, the lithology, thickness where available, and sources of data.

Because the classification of plutonic igneous rocks has changed since publication of many reports used in this study, the rock terminology in the original reports has been converted, where possible, to that adopted by the International Union of Geologic Sciences (IUGS), as reported by streckeisen (1976). Where changes have been made, the author's original term is enclosed by brackets following the IUGS term, for example, monzogranite [quartz monzonite]. Where no term is shown in brackets, either the original rock terminology conforms to the IUGS classification, or the published data are insufficient to determine the appropriate IUGS rock name. The lithologic designation as part of a formal or informal geologic name has not been modified to conform to IUGS terminology. The terminology of the silicic, shallow-intrusive rocks is that of the original author. 
Caution should be used when $\mathrm{Rb}-\mathrm{Sr}$ ages on Proterozoic rocks in New Mexico are being considered. Bowring and others (1983) indicate that many such reported ages appear to be too young.

Conversion Factors

\begin{tabular}{llc}
\hline To convert from & \multicolumn{1}{c}{ to } & Multiply by \\
\hline inch $($ in. $)$ & milimeter $(\mathrm{mm})$ & 25.4 \\
foot $(\mathrm{ft})$ & meter $(\mathrm{m})$ & 0.3048 \\
mile $(\mathrm{mi})$ & kilometer $(\mathrm{km})$ & 1.609 \\
mile $\left(\mathrm{mi}^{2}\right)$ & kilometer $\left(\mathrm{km}^{2}\right)$ & 2.590
\end{tabular}


DESCRIPTION OF MAP UNITS

[Radiometric ages determined by one of the following methods: (1) Rb-Sr whole-rock,

(2) U-Pb zircon, (3) K-Ar biotite, (4) Fission-track apatite, (5) K-Ar feldspar,

(6) K-Ar whole-rock, (7) K-Ar on unspecified material]

\begin{tabular}{|c|c|c|c|c|c|}
\hline $\begin{array}{l}\text { County- } \\
\text { area } \\
\text { number }\end{array}$ & $\begin{array}{c}\text { Map } \\
\text { symbol }\end{array}$ & $\begin{array}{l}\text { Pluton or } \\
\text { geologic } \\
\text { unit }\end{array}$ & $\begin{array}{l}\text { Geologic and } \\
\text { radiometric age } \\
\text { in millions of } \\
\text { years (m.y.) }\end{array}$ & Lithology and comments & $\begin{array}{l}\text { References } \\
\text { for } \\
\text { county area }\end{array}$ \\
\hline
\end{tabular}

BERNALILLO COUNTY (BE)

BE-1

$\begin{array}{lll}\text { Ymg North Sandia } & \text { Middle } \\ \text { pluton } & \text { Proterozoic } \\ & \left.1,445 \mathrm{~m} \cdot \mathrm{Y} \cdot \mathrm{(}^{1}\right)\end{array}$
Yqd $\begin{aligned} & \text { South Sandia } \\ & \text { pluton }\end{aligned}$

Bgn

Cibola Gneiss

Early

Proterozoic(?

$\left.1,580 \mathrm{~m} \cdot \mathrm{Y} \cdot \mathrm{(}^{1}\right)$

BE-2

Bgn

Middle Proterozoic $\left.1,440 \mathrm{~m} \cdot \mathrm{Y} \cdot \mathrm{(}^{2}\right)$ $1,445 \mathrm{~m} \cdot \mathrm{Y} \cdot(1)$
Manzanita pluton(?)
Sandia Granite described as north and south plutons by Condie and Budding

(1979), but Brookins and Majumdar (1982) favor only one pluton with internal chemical variations.

Homogeneous gray to pink, porphyritic, biotite monzogranite, granite, quartz monzonite containing accessory magnetite and sphene and traces of muscovite, tourmaline, and pyrite locally. Contains numerous small mafic and granitoid inclusions, and locally encloses zones of orbicular granite. Weathers to spheroidal boulders. Apparently much more extensive in subsurface. cut by numerous small faults.

Gray to pink, medium- to coarse-grained, porphyritic, biotite-quartz diorite containing accessory magnetite and sphene.

Aplite and pegmatite dikes are common; numerous mafic inclusions. Weathers to spheroidal boulders. Apparently much more extensive in subsurface.

Pink and red, medium-grained, porphyritic or porphyroblastic, biotite granite gneiss. Unit intrudes Early Proterozoic metamorphic rocks and is overlain unconformably by Pennsylvanian sedimentary rocks and by alluvium.

Orange to red, coarse-grained, strongly foliated monzogranite gneiss [quartz monzonite]. Called a pluton by condie and Budding (1979), and a metarhyolite by Myers and McKay (1970), stark and Dapples (1946), and Reiche (1949).

Probably much more extensive in subsurface. Intrudes(?) lower proterozoic metamorphic rocks and overlain unconformably by Pennsylvanian sedimentary rocks and by alluvium.
Brookins, 1982; Brookins and

Majumdar, 1982; Condie and Budding, 1979;

Kelley and

Northrup, 1975;

Myers and McKay 1970, 1976;

Reiche, 1949.

steiger and

Wasserburg, 1966 .

Taggert and

Brookins, 1975
Cavin and others, 1982 .

Condie and

Budding, 1979;

Myers and

McKay, 1970;

Reiche, 1949.

Stark and

Dapples, 1946

$\begin{array}{ll}\text { CA-1 Trd } \quad \begin{array}{l}\text { Rhyodacite } \\ \text { porphyry of } \\ \text { Cerrito viejo }\end{array} & \text { Oligocene(?) }\end{array}$

Greenish-gray, crystal-rich, rhyodaciteporphyry stock. Abundant large phenocrysts of plagioclase; also quartz, hornblende, and biotite.
Lopez and Bornhorst, 1979 . Willard and Givens, 1958 
DOÑA ANA COUNTY (DA)

DA-1

Ysg

Mayberry
pluton

San Andres

Ymg San And
pluton

Tqm

Organ

batholith

oligocene

32.8 to

$34.4 \mathrm{~m} \cdot \mathrm{y} \cdot$ ( $\left.^{3}\right)$

Tr

Rhyolite of Quartzite

Mountain
Middle

Proterozoic

Middle

Proterozoic
Oligocene

Mineral Hill Middle pluton
White to buff, medium- to coarsegrained, biotite syenogranite [granite], containing accessory biotite, zircon, apatite, magnetite, and allanite. Intrudes lower Proterozoic quartzite and amphibolite. Overlain nonconformably by paleozoic sedimentary rocks and by alluvium.

White to red, medium-grained, biotite monzogranite [quartz monzonite]; accessory or secondary magnetite, sphene, muscovite, epidote, and calcite. Intrudes lower Proterozoic amphibolite and gneiss. Overlain nonconformably by Paleozoic sedimentary rocks and by alluvium.

Southern San Andres and adjacent Organ Mountains largely underlain by three Proterozoic plutons and by the Tertiary organ batholith and subsidiary rhyolite. From north to south, the plutons are the Mineral Hill, exposed east of Goat and Quartzite Mountains, the White Sands pluton, south of White Sands, and the Organ, west of old coe Lake.

Composite batholith of alkalic affinity; Predominantly quartz monzonite, but ranges from monzodiorite through monzonite, quartz syenite, cuartz alkalicfeldspar syenite, to alkali-feldspar granite. Complex contains too little modal quartz to be classified as granite. Biotite and hornblende in all phases, and as much as 10 percent pyroxene in monzodiorite. Color mostly light tan to medium gray; grain size from fine to very coarse. Batholith intrudes Proterozoic granite, Paleozoic sedimentary rocks, and Tertiary volcanic rocks, and overlain by alluvium and colluvium.

Sills of light-gray to pale-orange rhyolite containing biotite and phenocrysts of quartz. Satellitic offshoot of Organ batholith. Has mineral composition of quartz alkali-feldspar syenite. Intrudes Pennsylvanian limestone. Estimated 300 to $400 \mathrm{ft}$ thick locally, based on topography .

Predominantly white to buff, equigranular, fine- to coarse-grained, biotite monzogranite [quartz monzonite] containing accessory or secondary magnetite, sphene, and muscovite. Biotite schlieren and inclusions of amphibolite abundant locally. Intruded by numerous Precambrian dikes of diabase and diorite. Highly fractured and altered locally. Intrudes lower Proterozoic quartzite. Overlain nonconformably by Paleozoic sedimentary rocks and by alluvium.
Bachman and

Myers, 1963, 1969;

Condie, 1981 ; Condie and

Budding, 1979;

Dane and

Bachman, 1961
Bachman and Myers, 1969; Condie, 1981. Condie and Budding, 1979; Dane and

Bachman, 1961;

Dunham, 1935;

Loring and Loring, 1980;

Seager, 1981 


$\begin{array}{ccl}\text { DA-3 } & \text { Ymg } & \begin{array}{l}\text { San Diego } \\ \text { Mountain } \\ \text { pluton }\end{array} \\ \text { DA-4 } & \text { Tm } & \begin{array}{l}\text { Summerford } \\ \text { Mountains } \\ \text { laccolith } \\ \text { and other } \\ \text { shallow } \\ \text { intrusive } \\ \text { rocks }\end{array}\end{array}$

DA-5 Trd $\begin{aligned} & \text { Flow-banded } \\ & \text { rhyolite of } \\ & \text { Cedar Hills }\end{aligned}$

\begin{tabular}{|c|c|c|c|}
\hline \multirow[t]{2}{*}{$\mathrm{DA}-6$} & $\mathrm{Ta}$ & $\begin{array}{l}\text { Andesite of } \\
\text { Faulkner } \\
\text { Canyon }\end{array}$ & $\begin{array}{l}\text { Oligocene } \\
31.5 \mathrm{~m} \cdot \mathrm{y} \cdot\left({ }^{7}\right)\end{array}$ \\
\hline & $\operatorname{Tr}$ & $\begin{array}{l}\text { Rhyolite } \\
\text { porphyry } \\
\text { of Robledo }\end{array}$ & $\begin{array}{l}\text { Oligocene } \\
35 \mathrm{~m} \cdot \mathrm{y} \cdot\left({ }^{7}\right)\end{array}$ \\
\hline
\end{tabular}

DA-7 Ta Mt. Riley- Tertiary
White Sands and organ plutons

Middle

Proterozoic

Middle

Proterozoic

oligocene

Oligocene rhyolite of

Mt. Cox pluton
Coarse-grained, gray, biotite monzogranite [quartz monzonite, granite]. White Sands pluton is porphyritic and intruded by several dikes of diabase to diorite. Organ pluton, of Condie and Budding (1979), not to be confused with Tertiary Organ batholith, is equigranular and intruded by numerous dikes of Precambrian diabase to diorite and Tertiary rhyolite. Both plutons intruded by organ batholith and overlain by alluvium. In addition, organ pluton is overlain unconformably by Cambrian-Ordovician Bliss Sandstone.

Predominantly red, coarse-grained, microcline monzogranite [granite, quartz monzonite]. Locally gneissic; contains schist and amphibolite inclusions. Deeply weathered and poorly exposed. overlain unconformably by CambrianOrdovician Bliss Sandstone and Quaternary conglomerate and alluvium. Fault bounded.

stocks, laccoliths, sills, dikes, and plugs of Doña Ana cauldron. Principally pale-yellowish-brown to light-gray, coarsely porphyritic to subequigranularphaneritic, biotite-augite monzonite porphyry. Includes some latite and trachyte. Some small masses of variably colored, flow-banded rhyolite porphyry, and of andesite and basaltic andesite.

Flow-banded, gray, yellow, or pink, locally spherulitic, massive to porphyritic rhyolite, forming small intrusive to extrusive domes. At least 21 oval to circular dome-flow complexes from one-third to two-thirds $\mathrm{mi}$ in diameter; many combined on map. Intrudes and overlies air-fall tuffs. Unit lies between tuffs dated at 35 to $39 \mathrm{~m} . \mathrm{y}$. old.

Dark-gray to black, finely porphyritic, biotite andesite. Numerous dikes and small masses.

Condie and Budding, 1979; Condie, 1981; Seager and others, 1971

Seager and others, 1976

Clemons, 1976; Seager and Clemons, 1975

Creamy-yellow to white, massive, porphyritic rhyolite. Phenocrysts of sanidine, quartz, and plagioclase. Feldspars generally altered to sericite, kaolin. and carbonate. Irregular masses and sills.

Stock of fine-grained, light-colored, micro-porphyritic andesite to rhyodacite porphyry. Moderately to highly altered; feldspars replaced by sericite and clay, and biotite by chlorite and hematite. Secondary calcite and silica locally. Contacts largely covered by talus.
Kottlowski 1960a;

Seager and

Clemons, 1975

Hoffer, 1976 ;

Millican, 1971 
GR-1 $\quad$ Tr

oligocene

GR-2 $\quad \operatorname{Tr}$

GR-3

\begin{tabular}{|c|c|c|}
\hline Tql & $\begin{array}{l}\text { Rhyolite sill } \\
\text { and dome of } \\
\text { Lampbright } \\
\text { Draw }\end{array}$ & Oligocene; \\
\hline $\mathrm{Tg}$ & $\begin{array}{l}\text { Silver City } \\
\text { stock, Eighty } \\
\text { Mountain-Gomez } \\
\text { Peak stock, and } \\
\text { other small } \\
\text { stocks }\end{array}$ & Early Tertiary \\
\hline TKg & $\begin{array}{l}\text { Piños Altos } \\
\text { stock and } \\
\text { other stocks }\end{array}$ & $\begin{array}{l}\text { Early Tertiary } \\
\text { or Cretaceous }\end{array}$ \\
\hline TKa & $\begin{array}{l}\text { Bear Mountain } \\
\text { laccolith and } \\
\text { other unnamed } \\
\text { masses }\end{array}$ & $\begin{array}{l}\text { Early Tertiary } \\
\text { or Cretaceous }\end{array}$ \\
\hline $\mathrm{Bg}$ & $\begin{array}{l}\text { Piños Altos } \\
\text { stock }\end{array}$ & $\begin{array}{l}\text { Middle } \\
\text { Proterozoic }\end{array}$ \\
\hline
\end{tabular}

GR-4
Oligocene

30.5 and

$30.8 \mathrm{~m} \cdot \mathrm{y} \cdot\left(^{3}\right)$

Proterozoic
Tgd

Tmg

TKu
Hanover-Fierro Early Tertiary pluton

Santa Rita stock
Early Tertiary

Tertiary and Cretaceous
Medium-gray to pale-reddish-gray porphyritic quartz latite to rhyolite.

Flow banded and glassy near contacts. Phenocrysts of feldspar, quartz, biotite, and hornblende in cryptocrystalline matrix. Irregular masses with sill-like and dike-like parts.

Pale-red, light-gray, and light-pinkish- Finnell, 1976a, gray, porphyritic rhyolite in plugs, domes, and dike-like masses. Contains phenocrysts of plagioclase, sanidine. and biotite. As much as $440 \mathrm{ft}$ thick locally.

Light-grayish-yellow to pale-reddishpurple, porphyritic, biotite, quartzlatite to rhyolite plugs, sills, and dikes generally no more than $1 \mathrm{mi}^{2}$ in area; may be in part extrusive.

$1976 \mathrm{~b}$

Hornblende quartz-diorite porphyry, containing white andesine phenocrysts, granodiorite porphyry, and hornblendebiotite monzogranite [quartz monzonite] as plugs, sills, and dikes.

Light-pinkish-gray hornblende monzogranite [quartz monzonite] porphyry and augite-biotite syenodiorite to monzonite of variable color and texture.

Light-olive-gray, hornblende-andesite porphyry. The largest, the Bear

Mountain laccolith, approximately $1 \mathrm{mi}^{2}$

in area, may be as much as 1,200 ft thick. Other masses are sills and dikes.

Porphyritic biotite granite. Covered by no more than a few hundred feet of Paleozoic strata.

Economically important base- and precious-metal mineralization associated with Tertiary and Cretaceous plutons.

Area contains the Hanover-Fierro and Santa Rita stocks, and many dikes, sills, and laccoliths. Economically important base- and precious-metal mineralization.

Aldrich, 1974; Hernon and others, 1964; Kuellmer, 1956 unningham

1974; Finnell, $1976 \mathrm{a}, 1976 \mathrm{~b}$; Jones and others, 1970
Mainly granodiorite porphyry.

Monzogranite [quartz monzonite] porphyry .

Undescribed intrusive masses. 
Kqd

Cretaceous

GR-5

Tq1

Cameron Creek laccolith

GR-6

Yg

Granite of silver City Range

Tr

Rhyolite of Saddle Mountain

Tqma

Quartz monzonite of Tyrone
TKa

TKr
Twin Peaks

Monzonite

Porphyry of

Hewitt (1959)
Early Tertiary

Middle

Proterozoic

Eocene and

(or) Paleocene

Paleocene

$\left.56 \mathrm{~m} \cdot \mathrm{Y} \cdot \mathrm{(}^{3}\right)$
Paleocene and (or) Late Cretaceous

Early Tertiary and (or) Late Cretaceous

\section{Late}

Cretaceous

$\left.72 \mathrm{~m} \cdot \mathrm{Y} \cdot \mathrm{(}^{3}\right)$
Large sills and laccoliths, predominantly hornblende-quartz diorite, but includes some rhyolite porphyry, augitehornblende-andesite porphyry, trachyte porphyry, and rock described as syenodiorite porphyry.

Biotite-quartz-latite porphyry. Phenocrysts of plagioclase, biotite, and quartz. Pervasive argillic alteration has produced secondary montmorillonite, sericite, chlorite, magnetite, sphene, and calcite. Intrusive into Pennsylvanian Oswaldo Limestone.

Mostly medium-grained, pink granite containing muscovite; locally biotite rich and porphyritic. Intrusive into Proterozoic metamorphic schist and quartzite. Overlain unconformably by Cambrian-ordovician sandstone and by alluvium. Faulted along southwestern side.

Big Burro Mountains area contains igneous rocks of variable ages, compositions, and structures; also includes metamorphic rocks, which in northern part were not mapped separately from Precambrian granitic rocks.

Light-colored, porphyritic rhyolite having generally aphanitic groundmass and phenocrysts of sanidine and quartz. Largest outcrop is sheet-like intrusion perhaps as much as $300 \mathrm{ft}$ thick, and smaller outcrops are plugs.

Medium-light-gray, medium-grained, holocrystalline, massive to weakly foliated, biotite quartz monzodiorite [quartz monzonite]; trace amounts of hornblende and accessory sphene, apatite, and iron oxides. Composes a large stock intrusive into granite of Burro Mountain (Ymg) and mineralized near contacts.

Light-reddish-brown, yellowish-brown, or light-brownish-gray, hornblende-andesite porphyry. Contains accessory magnetite, apatite, and zircon, and much secondary clay, sericite, chlorite, and calcite. Deeply weathered or hydrothermally altered.

Light-gray and light-tan to reddishbrown rhyolite porphyry containing phenocrysts of orthoclase and quartz in matrix of fine-grained orthoclase and quartz.

Medium-light-gray, quartz monzodiorite(?) [monzonite] porphyry; phenocrysts of andesine, hornblende, and minor orthoclase in matrix of cryptocrystalline feldspar and minor quartz.
Pratt, 1967;

Pratt and

Jones, 1965
Condie, 1981 ;

Cunningham, 1974
Hedlund, 1978a,

$1978 \mathrm{~b}, 1978 \mathrm{c}$ $1978 \mathrm{~d}, 1978 \mathrm{e}$ $1980 \mathrm{a}, 1980 \mathrm{~b}$

Hewitt, 1959 .

McDowe11， 1971; Trauger, 1972 
Ygd

Ysg

Granite of Burro Mountain
Middle

Proterozoic

$1,445 \mathrm{~m} \cdot \mathrm{y} \cdot\left({ }^{2}\right)$

Middle

Proterozoic

$\left.1,380 \mathrm{~m} \cdot \mathrm{y} \cdot \mathrm{(}^{3}\right)$

Middle

Proterozoic
Ygn

Granite of Burro Mountain
GR-8

Vista monzonite Tertiary(?) or granodiorite of Elston (1957)
Middle

Proterozoic

Middle

Proterozoic

$\left.1,550 \mathrm{~m} \cdot \mathrm{y} \cdot \mathrm{(}^{3}\right)$
Ysg
Middle

Proterozoic(?)
Medium-1ight-gray, coarse-grained, hornblende-biotite granodiorite to monzogranite. Accessory sphene, apatite, epidote, and iron oxides. Locally porphyritic.

Medium-1ight- to light-pinkish-gray, medium- to coarse-grained, leucocratic syenogranite; accessory biotite, sphene, and white mica.

Medium-1ight-gray to light-pinkish-gray, medium-grained, biotite monzogranite [granite]; massive to locally gneissic; accessory zircon, epidote, white mica, iron oxides. Titanium mineralization in pegmatites. Cut by swarms of rhyolite dikes of Tertiary age. Intrudes Middle Proterozoic Bullard Peak series of Hewitt (1959). Overlain unconformably by Cambrian-Ordovician Bliss Sandstone, Cretaceous Beartooth Quartzite, and alluvium.

Undifferentiated feldspathic gneisses of Bullard Peak series of Hewitt (1959) and granodiorite both of Middle Proterozoic age.

Medium-light-gray to light-pinkish-gray, medium-grained, biotite monzogranite [granite] and gneissic monzogranite. Accessory zircon, sphene, apatite and iron oxides. Intrusive into Middle Proterozoic gneiss of the Bullard Peak series of Hewitt (1959), and overlain unconformably by Tertiary ash-flow tuffs and by alluvium. Intruded locally by swarms of Tertiary rhyolite dikes and cut by numerous small faults.

Highly altered rock consisting of sericitized plagioclase phenocrysts, chloritized ferromagnesian minerals, and groundmass altered to sericite. Probably small plug in which grain sizes decrease toward the margins. Strongly fractured and cut by veins of quartz, potassiumfeldspar, and fluorite.

Massive, coarse-grained, pale-reddishgray to light-greenish-gray biotite granite and pegmatite. Epidotized and foliated locally. Cut by Tertiary(?) rhyolite dikes. Overlain unconformably by Cambrian-Ordovician Bliss Sandstone and by alluvium. Fault on northeastern side.
Gillerman, 1964; Hedlund, 1978f, $1978 \mathrm{~g}, 1978 \mathrm{~h}$

$1978 i, 1980 b$

Elston, 1957

Condie, 1981;

Elston, 1957

Jicha, 1954 
HI-2 Bg

$\mathrm{HI}-3$

Tgd $\begin{aligned} & \text { Lordsburg } \\ & \text { stock }\end{aligned}$

$\operatorname{Tr}$

HI -4

$\mathrm{Tm}$

HI -5
Miocene or oligocene

oligocene 30 to $33 \mathrm{~m} \cdot \mathrm{y} \cdot\left(^{7}\right)$

Oligocene 28 to $\left.33 \mathrm{~m} \cdot \mathrm{y} \cdot \mathrm{(}^{4}\right)$

Middle

Proterozoic

Tertiary

Tertiary

Middle

Proterozoic
Undifferentiated rocks, perhaps granite.

Principally light-gray to light-

brownish-gray, fine- to medium-grained,

biotite-hornblende granodiorite porphyry and minor monzogranite [quartz monzonite]. Accessory zircon, sphene,

apatite, and magnetite. Strongly frac-

tured and altered. Intrusive into cretaceous andesite and sandstone.

Minor intrusive masses of pinkish-orangegray aplite and light-gray to greenishgray rhyolite porphyry. Overlain by alluvium.

Light-greenish-gray, tan-weathering, pyroxene monzonite. In part concealed by alluvium, but location of several

small masses of monzonite east of main stock suggests that stock may be more extensive in subsurface. Intrusive into Tertiary andesite.

Grayish-brown to dark-reddish-brown, biotite-rhyodacite porphyry forming irregular mass that is in part a sill. Accessory magnetite, apatite, zircon, and sphene.

Pinkish-gray, biotite-quartz monzonite to monzonite stock, dikes, and sills. Contains accessory magnetite, apatite, sphene, zircon, and allanite.

Fine-grained, biotite-quartz-latite porphyry, forming dikes, sills, and irregular masses. Accessory magnetite, apatite, and zircon.

Brownish-gray, very coarse grained, porphyritic, biotite granodiorite, locally gneissic. In fault contact with Paleozic sedimentary rocks and intruded by Tertiary rocks. Overlain by alluvium.

olive-gray, brown-weathering, latiteporphyry stock. Phenocrysts of orthoclase and andesine. Intrusive into Tertiary rhyolite tuff, but may be extrusive locally. Overlain by alluvium. Incompletely mapped and described.

Dull-red- to brown-weathering, biotite monzogranite(?) [quartz monzonite] porphyry. Accessory sphene, apatite, and opaque minerals. Secondary chlorite and epidote.

Brownish-pink, very coarse grained, porphyritic, biotite granite. Cataclasis widespread; poorly exposed except where incised by streams; exposures are of grus.
Dane and

Bachman, 1961

Flege, 1959;

Thorman and

Drewes, 1978

Flege, 1959

Drewes and Thorman, 1980a, 1980b

Wrucke and

Bromfield, 1961; Dane and

Bachman, 1961

Condie, 1981; Soule, 1972;

Zeller, 1958 


\begin{tabular}{|c|c|c|c|c|c|}
\hline \multirow[t]{2}{*}{ HI -8} & Tmg & $\begin{array}{l}\text { Animas stock: } \\
\text { Animas Quartz } \\
\text { Monzonite }\end{array}$ & Tertiary & $\begin{array}{l}\text { Pinkish-gray, locally flow-banded, bio- } \\
\text { tite monzogranite [quartz monzonite] } \\
\text { porphyry; } 20 \text { to } 70 \text { percent phenocrysts } \\
\text { of plagioclase, orthoclase, and biotite } \\
\text { in microcrystalline to fine-grained } \\
\text { matrix. Intrudes Tertiary volcanic } \\
\text { rocks. }\end{array}$ & $\begin{array}{l}\text { Zeller, 1962; } \\
\text { Zeller and } \\
\text { Alper, } 1965\end{array}$ \\
\hline & Tqm & $\begin{array}{l}\text { Walnut Wells } \\
\text { plug: } \\
\text { Walnut Wells } \\
\text { Monzonite }\end{array}$ & Tertiary & $\begin{array}{l}\text { Light-grayish-green, biotite-pyroxene, } \\
\text { quartz-monzonite [monzonite] porphyry; } \\
20 \text { to } 45 \text { percent phenocrysts of plagio- } \\
\text { clase, orthoclase, clinopyroxene, and } \\
\text { biotite in microcrystalline matrix. } \\
\text { Intrudes Tertiary volcanic rocks. }\end{array}$ & \\
\hline \multirow[t]{3}{*}{ HI -9 } & $\mathbf{T g}$ & $\begin{array}{l}\text { Stock in } \\
\text { Granite Pass }\end{array}$ & Tertiary & $\begin{array}{l}\text { Pink, Coarse-grained, seriate-porphy- } \\
\text { ritic, biotite granite. Weathers to } \\
\text { pebbly grus and residual boulders and } \\
\text { masses. Intrusive into Middle Protero- } \\
\text { zoic granite, Pennsylvanian limestone, } \\
\text { and Cretaceous sandstone and shale. } \\
\text { Overlain by alluvium. }\end{array}$ & $\begin{array}{l}\text { Condie, 1981; } \\
\text { Lasky, 1947; } \\
\text { Zeller, } 1970 \\
1975\end{array}$ \\
\hline & & $\begin{array}{l}\text { Old Hachita } \\
\text { stock }\end{array}$ & $\begin{array}{l}\text { Tertiary and } \\
\text { (or) Cretaceous }\end{array}$ & $\begin{array}{l}\text { Augite-hornblende quartz monzonite and } \\
\text { highly altered sodic-augite-hornblende } \\
\text { quartz monzonite(?) [monzonite] in } \\
\text { which albite has replaced part of the } \\
\text { andesine. Outcrop northeast of Howells } \\
\text { Ridge. }\end{array}$ & \\
\hline & Ysg & & $\begin{array}{l}\text { Middle } \\
\text { Proterozoic }\end{array}$ & $\begin{array}{l}\text { Gray, coarse-grained, porphyritic, bio- } \\
\text { tite syenogranite(?) [granite], showing } \\
\text { rapikivi texture locally. Accessory apa- } \\
\text { tite, zircon, sphene, and magnetite. Cut } \\
\text { by dikes and irregular masses of aplite. }\end{array}$ & \\
\hline
\end{tabular}

LINCOLN COUNTY (LI)

LI-1 Tr

oligocene(?)

Laccolith of white to buff, very fine

Perhac, 1970

grained, porphyritic rhyolite. Small

miarolitic cavities filled with quartz

and kaolinite. Contains biotite,

aegirine, and aegirine-augite. More

than $500 \mathrm{ft}$ thick near Gallinas Peak. 


\begin{tabular}{|c|c|c|c|}
\hline LI - 2 & $\mathrm{Ti}$ & $\begin{array}{l}\text { Cerro Tecolote } \\
\text { laccolith }\end{array}$ & oligocene(?) \\
\hline LI -3 & $\mathrm{Tm}$ & $\begin{array}{l}\text { Jicarilla } \\
\text { monzonite of }\end{array}$ & oligocene(?) \\
\hline
\end{tabular}

LI -4
Patos laccolith

Carrizo laccolith
Tertiary

Tertiary

Tertiary

Tertiary
Laccolith of trachyte containing lensshaped masses of microsyenite. White to light-gray, porphyritic trachyte containing prominent orthoclase and albite phenocrysts in aphanitic matrix of albite, orthoclase, and minor hornblende and aegirine-augite. More than 500 ft thick.

Stock(?) of 1ight-gray, porphyritic latite, containing phenocrysts of horn blende and plagioclase in groundmass of very fine grained potash feldspar.

Mainly diorite and syenite. Also included in sil1s, dikes, and other laccoliths.

Stocks or laccoliths of gray to buff, leucocratic, monzonite porphyry. Euhedral plagioclase crystals as much as one in. long and anhedral, embayed quartz phenocrysts. Hornblende and biotite are generally altered to chlorite. Sericitization of feldspars is pronounced.

Parts of two large laccoliths and several smaller stocks, dikes, and laccoliths(?).

Most of pluton occurs east of study area; consists of hornblende and biotite trachyte porphyry.

Biotite-hornblende-quartz-syenite porphyry. Although the Patos and Carrizo masses are called laccoliths, there is no evidence that they are floored (Weber, 1964).

Larger of three masses west of Carrizo laccolith identified as a stock, and elongate mass southeast of Carrizo laccolith identified as a sill by Kelley and Thompson (1964). Neither has been described.

Alkali-syenite sills, associated feeder dikes, and a plug-like mass. Southernmost outcrop is sill of analcite-syenite porphyry, connected to feeder dike on east side. Rock contains phenocrysts of orthoclase and smaller crystals of augite, rimmed by aegerite, in a matrix of altered albite(?) and analcite. Cub Mountain mass, which appears to be a feeder plug, is of similar composition but contains some nepheline. Northernmost outcrop is a sill as much as $800 \mathrm{ft}$ thick of fine-grained leucosyenite, containing glomerocrysts of albite and minor aegerine-augite and biotite in matrix of altered orthoclase. Dark-colored, lamprophyric intrusives associated with some syenites.
Rawson, 1957

Budding, 1964; Kelley and Thompson, 1964 ; Smith and Budding, 1959

Budding, 1964

Butler, 1964:

Kelley and Thompson, 1964; Weber, 1964
Kelley and Thompson, 1964; Weber, 1964 
Oligocene, $25.8 \mathrm{~m} . \mathrm{y}$. ( $^{5}$ )
Small, hypabyssal intrusive masses, undescribed.

Sierra Blanca area, mostly east of study area, is underlain by complex sequence of volcanic rocks (Sierra Blanca volcanics of Thompson, 1973) composed of stocks, sills, and dikes. Two of the stocks extend into study area.

Predominantly hornblende-biotite monzonite containing less than 5 percent quartz.

Leucosyenite porphyry, containing abundant phenocrysts of anorthoclase and minor amounts of hornblende and biotite.
Kelley and Thompson, 1964; Thompson, 1973; Weber, 1964

\section{LUNA COUNTY (LU)}

$\begin{array}{lll}\text { LU-1 Tgd } & \begin{array}{l}\text { Cooks Peak } \\ \text { Granodiorite }\end{array} & \begin{array}{l}\text { Oligocene or } \\ \text { Eocene } \\ 38.8 \mathrm{~m} \cdot \mathrm{y} \cdot\left({ }^{3}\right)\end{array}\end{array}$

$\mathbf{B}$

LU-2 Tr

LU-3

\author{
Rhyolite of \\ Little Florida \\ Mountains \\ Mountains
}

Proterozoic

Oligocene $23.6 \mathrm{~m} \cdot \mathrm{y} \cdot\left(^{6}\right)$

$\begin{array}{ll}\text { Mzg(?), } & \text { Granite of } \\ \text { Yg } & \text { Florida } \\ & \text { Mountains }\end{array}$

Mesozoic(?) or Paleozoic(?) and Middle Proterozoic
Stocks or laccoliths of massive, gray, hornblende-biotite, granodiorite porphyry with microcrystalline groundmass. Intrudes Paleozoic and Cretaceous sedimentary rocks and in fault contact with Tertiary volcanic rocks. Overlain by Quaternary terrace gravels. All masses may join in subsurface.

Undifferentiated dark-gray syenogranite, red pegmatitic granite, amphibolite, feldspathic gneiss, and schist.

Irregular domal and dike-like intrusions and short, lava flows of grayishpink and pale-red to dark-grayish-red. massive to flow-banded rhyolite. Very finely crystalline, dominantly autobrecciated texture. Apparently the vent of a volcano.

Medium- to coarse-grained granite containing chlorite replacing biotite; apparently mostly syenogranite but no published modal analyses. Called granite and syenite by some authors. Age relations not clear. $\mathrm{Rb}-\mathrm{Sr}$ whole-rock ages range from about $1,440 \mathrm{~m}$.y. to about $300 \mathrm{~m} . \mathrm{y}$. , and dates cluster around $1,100 \mathrm{~m} \cdot \mathrm{y}$. and 400 to $550 \mathrm{~m} \cdot \mathrm{y}$. K-Ar and $\mathrm{Rb}-\mathrm{Sr}$ mineral ages also cluster between 400 and $550 \mathrm{~m} \cdot \mathrm{y}$. Part of southern mass appears to be Middle Proterozoic, and at least part of northern mass may be Paleozoic or Mesozoic. In part overlain unconformably by Paleozoic sedimentary rocks, but in part possibly intrusive into Paleozoic rocks.
Clemons, 1982b; Elston, 1957;

Griswald, 1961;

Jicha, 1954

Loring and

Loring, 1980
Brookins, 1974; Condie, 1981; Corbitt, 1971 ;

Darton, 1917; Woodward, 1970 


LU-4 Tmg $\begin{aligned} & \text { Tres Hermanas } \\ & \text { stock }\end{aligned}$ Tertiary

Buff-colored, fine- to medium-grained, equigranular to prophyritic, hornblende monzogranite [quartz monzonite] to syenogranite [granite]. Prominent vertical joints. Intrudes Pennsylvanian limestone and Tertiary latite and andesite. Overlain by alluvial deposits. zinc, lead, silver, copper, and gold mineralization.
Balk, 1962; Doraibabu and Proctor, 1973

\section{OTERO COUNTY (OT)}

$\begin{array}{cccc}\text { OT-1 } & \text { Ti } & \text { Tertiary } \\ \text { OT-2 } & \text { Tqm } & \begin{array}{l}\text { Jarilla } \\ \text { Mountains } \\ \text { stock }\end{array} & \text { Tertiary } \\ \text { OT-3 } & \text { Ti } & & \text { Tertiary } \\ \text { OT-4 } & \text { Ts } & \begin{array}{l}\text { Wind Mountain } \\ \text { laccolith }\end{array} & \text { Tertiary }\end{array}$

Undescribed shallow-intrusive rocks. sills, dikes, stocks, and possibly laccoliths.

Composite pluton formed by at least three phases of intrusion. Most abundant and youngest lithology is gray to tan, fine-grained, hornblende-quartzmonzonite porphyry [monzonite-adamellite]. Smaller areas underlain by biotite monzodiorite [syenodiorite] and leucocratic, rhyolite porphyry. Extensively argillized and sericitized; contains disseminated sulfide minerals and cupriferous veins.

Undescribed shallow-intrusive rocks.

Nepheline-syenite porphyry, containing euhedral to subhedral nepheline, perthite, and pyroxene in fine-grained groundmass of feldspar and aegirite. widespread beryllium and zirconium mineralization. Numerous dikes as cone sheets and radiating vertical sheets around laccolith.
Dane and Bachman, 1965

Dane and Bachman, 1965; New Mexico Geological Society, 1982

Schmidt and Craddock, 1964

Warner and others, 1959

SANTA FE COUNTY (SF)

$\begin{aligned} \mathrm{SF}-1 \quad Y g \quad \text { Embudo Granite } & \text { Middle } \\ & \text { Proterozoic, } \\ & 1,460 \mathrm{~m} \cdot \mathrm{Y} \cdot\left({ }^{1}\right)\end{aligned}$

SF-2 Ti oligocene(?)
Biotite-bearing rock, ranging from monzogranite [quartz monzonite] to granodiorite and quartz diorite; description from outside of study area.

Stocks, plugs, laccoliths, and sills composed of monzonite and latite porphyry and small areas of syenitetrachyte prophyry and rhyolite porphyry.
Miller and others, 1963; Montgomery, 1953; Register and Brookins, 1979

Atkinson, 1961; Bachman, 1975; Disbrow and Stoll, 1957;

Stearns, 1953. Sun and Brewster, 1958 


\section{So-1 Ymg Ladron pluton: Middle}

Ladron quartz Proterozoic

monzonite of

Condie (1976)
$\mathrm{Yg}$

Capirote
pluton:
Capirote
granite of
Condie (1976)

so-2

Ysg La Joyita
pluton

Ygn

Middle Proterozoic(?)

so-3

Los Piños and
Sepultura
plutons:
Los Piños
granite of
Stark and
Dapples (1946)

Middle

Proterozoic(?)

Middle

Proterozoic(?) Proterozoic, $1,600 \pm 240$ and
Light-orange to buff, coarse-grained, uniform-textured, unfoliated, biotitemuscovite monzogranite [quartz monzonite]. Contains accessory magnetite and sphene. Locally epidotized, but generally fresh and unaltered. Unconformably overlain by pediment gravels and probably by older Phanerozoic sedimentary rocks. Intrudes the Capirote pluton and Early Proterozoic metaquartzite and metavolcanic rocks.

Heterogeneous pluton of biotite syenogranite to monzogranite [granite]. Four facies mapped by Condie (1976), distinguished by grain size, and degree of hydrothermal or deuteric alteration, and shearing. Coarse to medium grained, generally buff to rusty orange. Locally numerous inclusions, composing 20 to 40 percent of rock, which range in length from about one in. to several thousand $f t$. Overlain unconformably by alluvium and older phanerozoic sedimentary rocks. Intrudes Early Proterozoic metaquartzite and metavolcanic rocks.

Orange to red, coarse-grained, commonly foliated, biotite syenogranite [granite]. Contains accessory magnetite and muscovite, many inclusions of schist and quartzite, and numerous small pegmatites. cut by several northeast- and northwesttrending faults.

Medium- to coarse-grained, biotite gneiss approximately of monzogranitic to syenogranitic composition. Contains minor zones of amphibolite and irregular patches of foliated granite.

Middle or Early $1,350 \pm 106 \mathrm{~m} \cdot \mathrm{y} \cdot\left({ }^{1}\right)$

Los Piños and Sepultura plutons are massive, pink, medium- to coarsegrained, microcline-albite-biotite syenogranite, containing traces of muscovite and accessory magnetite and sphene. Cut by hornblende dikes and contain many xenoliths. Los Piños pluton on the north separated from sepultura pluton by a septum of metamorphic rocks. Although the Los Piños is dated at $1,600 \mathrm{~m} \cdot \mathrm{y}$. and the Sepultura as younger, the plutons may actually be the same age. Foliated near intrusive contacts with older Proterozoic metamorphic rocks. overlain by alluvial fan deposits.

Dikes and sills of variably colored, deeply weathered, fine-grained andesite. others, 1984 Thickness as much as $700 \mathrm{ft}$. Numerous small masses, not all shown on map.
Condie, 1976, 1981;

Condie and Budding, 1979; White, 1978

Condie, 1981; Condie and Budding, 1979, Herber, 1963

Brookins and others, 1980; Condie, 1981; Condie and Budding, 1979; Myers and others, 1981, 1984; Stark and Dapples, 1946

Myers and 
so-5

Middle

Proterozoic

SO 6

Upper

Miocene(?)

\begin{tabular}{|c|c|c|c|}
\hline so-7 & $\mathrm{Ti}$ & & Tertiary \\
\hline \multirow[t]{2}{*}{ so-8 } & $\mathrm{Ti}$ & & Tertiary \\
\hline & Ysg & $\begin{array}{l}\text { Magdalena } \\
\text { pluton }\end{array}$ & $\begin{array}{l}\text { Middle } \\
\text { Proterozoic } \\
1,275 \text { and } \\
1,355 \mathrm{~m} \cdot \mathrm{y} \cdot\left(^{1}\right)\end{array}$ \\
\hline
\end{tabular}

so-9

Proterozoic

so-10 Ti

Middle

Proterozoic

Ymgc

Capitol Peak pluton

Middle

Proterozoic

so-12

Proterozoic
Pink to tan, medium- to coarse-grained, biotite syenogranite [granite] containing accessory magnetite and traces of muscovite. Plagioclase saussuritized and biotite chloritized. Mortar texture common. Cut by northeast-trending metadiabase dikes. Intrudes Early

Proterozoic metagabbro.

Variably colored, dark-greenish-gray, aphanitic basalt and syenodiorite in sills, dikes, and plugs. Phenocrysts of olivine, hornblende, pyroxene, and biotite. Deeply weathered and cut by columnar joints perpendicular to

contacts. Intrusive into older sedimentary rocks. Mostly less than 200 to $300 \mathrm{ft}$ thick.

Intermediate to silicic porphyry.

Intermediate to silicic porphyry.

Pink to orange, fine- to coarse-grained, biotite syenogranite [granite]. Minor biotite is chloritized. Intrudes Early Proterozoic quartzite and metagabbro, which occur in masses as much as $1 \mathrm{mi} 2$ (not shown on map). Intruded by minor metadiabase. Unconformably overlain by Pennsylvanian sedimentary rocks and by unconsolidated Quaternary sediments. Faulted along east side.

Orange to buff, medium- to coarsegrained, biotite monzogranite [quartz monzonite]. Exposed in small fault blocks, but subsurface extent probably much greater. Cut by faults and fluorite-barite veins.

Monzonite, syenite, trachyte, and diorite in dikes, sills, and stocks, generally less than $300 \mathrm{ft}$ thick.

Gray to buff, medium-grained, locally porphyritic, biotite monzogranite [quartz monzonite] including minor hornblende. Probably younger than the oscura and Capitol Peak plutons.

Red to gray, medium- to coarse-grained, biotite monzogranite [quartz monzonite]. Locally porphyritic and foliated. Contains muscovite and accessory magnetite, sphene, zircon, and apatite.

Petrographically similar to and probably continuous in subsurface with Oscura pluton.

Granite, undescribed. Overlain by faulted Pennsylvanian sedimentary rocks and by alluvium. Near

Tertiary volcanic caldera.
Geological

Society, 1982

Condie, 1981; Budding, 1979

Tonking, 1957

Condie, 1981; Condie and Budding, 1979; Dane and Bachman, 1965; Loughlin and Koschmann, 1942 ;

New Mexico

Geological society, 1982;

Titley, 1959;

White, 1978 Budding, 1979; Dane and

Bachman, 1965

Kottlowski, 1953;

wilpolt and

Bachman, 1965, 1968;

Bachman and Harbour, 1970;

Budding and Condie, 1975; Condie and Budding, 1979;

White, 1978

Kottlowski, $1960 \mathrm{~b}$ Condie, and

Condie and Wanek, 1951 
SR-1

Tm

Tertiary

$\operatorname{Tr}$

Tertiary

Tg

Tertiary

$\mathrm{Ti}$

Tertiary

SR-2

Middle pluton

Proterozoic

SR-

$\operatorname{Tr}$

Rhyolite of

Salinas Peak

Tertiary

SR-4

Strawberry

Peak pluton

Middle

Proterozoic

SR-5

Proterozoic

SR-6

Caballo pluton Middle Proterozoic

Ys

Bgn
Gray, fine- to medium-grained, locally porphyritic monzonite as large plugs and laccoliths.

Medium to coarsely porphyritic rhyolite, having dense, aphanitic groundmass; as dikes and plugs.

Fine-grained aplite or granite, locally containing large pods of quartz; sills, dikes, and plugs.

Undescribed intrusive mass. Lead-zinccopper mineralization particularly associated with monzonite, and beryllium, iron, and tin mineralization with granite and rhyolite. Intrusive into Paleozoic sedimentary rocks and Tertiary sedimentary and volcanic rocks.

Heterogeneous, pink to white, mediumto coarse-grained, granitic rocks cut by abundant quartz veins. Overlain unconformably by Paleozoic rocks.

Sill of very fine grained rhyolite containing several percent muscovite and 1 percent calcite. Appears to be as much as 2,500 ft thick, based on topographic expression. Columnar jointing. Intrudes Paleozoic sedimentary rocks.

White to buff, medium- to coarsegrained, biotite syenogranite [granite], containing accessory allanite, apatite, zircon, and sphene. Biotite partly to completely replaced by chlorite. Intrudes Early proterozoic phyllite and quartzite; overlain unconformably by Paleozoic sedimentary rocks.

Pink granite containing small pegmatite dikes and inclusions of biotite schist. overlain unconformably by Paleozoic sandstone and limestone.

orange to buff, medium- to coarsegrained, biotite monzogranite [quartz monzonite].

Brick-red syenite and granite, suggestive of fenite.

Gneissic granite characterized by abundant inclusions of gneiss and mica schist.

All igneous rocks are intrusive into Early Proterozoic amphibolite, and overlain by Paleozoic sedimentary rocks.
Dane and

Bachman, 1961;

Jahns, 1955
Condie, 1981; Condie and Budding, 1979 ; Cserna, 1956; Dane and

Bachman, 1961; Jacobs, 1956; McCleary, 1960

Bachman and Harbour, 1970; Kottlowski and others, 1956

Condie, 1981; Condie and Budding, 1979; Dane and

Bachman， 1961

Kelley and Silver, 1952

Condie, 1981; Condie and Budding, 1979, Kelley and Silver, 1952; Staatz and others, 1965 
SR-7

\section{oligocene}

Middle Proterozoic Seven Brothers Mountain, granite of Dumm Canyon, granophyre of North Percha Creek

Medium- to olive-gray, fine-grained, weakly porphyritic, biotite-hornblendeclinopyroxene diorite. Contains andesine and hornblende phenocrysts and accessory apatite, white mica, and chlorite. Overlain by Tertiary volcanic rocks.

Medium-gray, medium-grained, hornblendequartz diorite. Contains small amounts of biotite and orthoclase, and accessory chlorite, epidote, sphene, and apatite. Irregular stock-like mass. Intrusive into Ordovician limestone.

Light-pinkish-gray to light-gray, fineto medium-grained, biotite-quartz syenite [quartz monzonite]. Contains euhedral laths of orthoclase, and some biotite and green hornblende. Accessory and secondary minerals include magnetite. sphene, zircon, apatite, epidote, calcite, chlorite, and white mica. Quartz veins contain copper and molybdenum-sulfide minerals. Intrudes Cretaceous andesite.

Light-pinkish-gray, medium-grained, biotite-hornblende monzogranite [quartz monzonite to granite] containing accessory sphene and apatite. Light-gray, medium-grained, hornblende-biotitequartz monzodiorite, containing accessory or secondary apatite, chlorite, ferric oxides, and white mica; forms a marginal facies along eastern edge of stock.

Medium-gray, phenocryst-rich andesite porphyry. Phenocrysts of sodic andesine in groundmass partly altered to calcite, white mica, and secondary quartz. Accessory oxyhornblende, biotite, and iron oxides. About 250 ft thick. Intrudes Pennsylvanian limestone and shale. Overlain by quartz-latite flow breccias.

Mostly rhyolite but some andesite in plugs, sills, and dikes. Rhyolite is light gray to light brownish gray, porphyritic, and contains sanidine and quartz phenocrysts and accessory biotite. Intrudes Paleozoic sedimentary rocks and Tertiary volcanic rocks.

Light-pinkish-gray, fine- to mediumgrained, or locally coarse-grained and porphyritic, biotite monzogranite [granite and granophyre]. Intrusive into Early Proterozoic metamorphic rocks and nonconformably overlain by Paleozoic sedimentary and Tertiary volcanic rocks.
Hedlund, 1977

Hedlund, 1977

Hedlund, 1977 


\section{TORRANCE COUNTY (TO)}

$\begin{array}{lll}\text { TO-1 Ygd } & \begin{array}{l}\text { Ojita pluton: } \\ \text { Granite of } \\ \text { Ojita stock of } \\ \text { Reiche (1949) }\end{array} & \begin{array}{l}\text { Middle } \\ \text { Proterozoic, }\end{array} \\ & \end{array}$

TO-2

Ysg

Pedernal

pluton:

Granite of

Pedernal Hills

Yg

Granite of Rattlesnake Hill
Light-gray to tan, massive, mediumgrained, biotite granodiorite to biotite monzogranite [quartz monzonite] containing accessory magnetite and sphene. Mafic inclusions and aplite dikes common; pegmatite dikes are rare. Encloses a large, but mostly concealed, irregular mass of quartzose and olivine gabbro. Intrudes Proterozoic metamorphic rocks; overlain unconformably by Pennsylvanian sedimentary rocks and alluvium. Thrust fault along eastern margin dips beneath pluton.

Pink to orange, fine- to coarse-grained biotite syenogranite [granite], ranging locally to alkali-feldspar granite

[alkali granite] and monzogranite [quartz monzonite]. Poorly exposed and weathered. Plagioclase saussuritized, and biotite partially chloritized.

Intrudes Proterozoic metamorphic rocks; overlain by alluvium. Cut by several north-trending faults.

Probably similar to granite of Pedernal Hills; no detailed description available. Pinkish granite gneiss dominates Rattlesnake Hill area. Granite and granite gneiss may be continuous beneath alluvium with granite of Pedernal Hills. partly covered by permian strata north of Rattlesnake Hill.
Brookins, 1982; Cavin and others, 1982 Myers and McKay, 1971; Reiche, 1949 . White, 1978

Condie, 1981; Condie and Budding, 1979; Gonzalez and Woodward, 1972 ; Kelley, 1972; Mukhopadhyay and others, 1975

\section{VALENCIA COUNTY (VA)}

\begin{tabular}{|c|c|c|}
\hline$V A-1$ & Ygd & $\begin{array}{l}\text { Monte Largo } \\
\text { pluton }\end{array}$ \\
\hline
\end{tabular}

$\mathrm{VA}-2$
Priest pluton: Granite of priest Canyon
Middle or Early Proterozoic $\left.\sim 1,600 \mathrm{~m} \cdot \mathrm{Y} \cdot \mathbf{(}^{1}\right)$
Dark-gray, brown-weathering, massive to locally gneissic, medium- to coarsegrained, hornblende granodiorite to monzogranite [granite, granodiorite, quartz monzonite]. Many schistose xenoliths and quartz lenticles. Pervasively altered to saussuritized feldspar, chlorite, biotite, and epidote. Intrudes Proterozoic metamorphic rocks; overlain by alluvium. Petrographically similar to Ojita pluton (TO-1).

Gray to pink, red-weathering, massive, coarse-grained, porphyritic, biotite monzogranite [quartz monzonite] to syenogranite. Xenoliths of schist and mafic rock. Plagioclase saussuritized, and biotite commonly partially chloritized and epidotized. Intrudes Proterozoic metamorphic rocks; has welldeveloped, contact-metamorphic aureole. Thrust over Pennsylvanian sedimentary rocks along eastern margin. Overlain by alluvium locally. See Dorman (1951) for study of fracture patterns.
Condie and Budding, 1979; Myers and McKay, 1972, 1974; stark, 1956

Brookins, 1982; Condie and Budding, 1979 ; Dorman, 1951; Myers, 1977; Myers and McKay, 1974; staatz and Norton, 1942; Stark, 1956; Stark and Dapples, 1946 
Aldrich, M. J., Jr., 1974, structural development of the HanoverFierro pluton, southwestern New Mexico: Geological Society of America Bulletin, v. 85, no. 6, p. 963-968.

Atkinson, W. W., Jr., 1961, Geology of the San Pedro Mountains, Santa Fe County, New Mexico: New Mexico Bureau of Mines and Mineral Resources Bulletin 77, $50 \mathrm{p}$.

Bachman, G. O., 1965, Geologic map of the Capitol Peak NW Quadrangle, Socorro County, New Mexico: U.S. Geological survey Miscellaneous Geologic Investigations Map I-441, scale $1: 31,680$.

1968, Geology of the Mockingbird Gap Quadrangle, Lincoln and Socorro Counties, New Mexico: U.S. Geological Survey Professional Paper 594-J, p. J1-J43.

1975, Geologic map of the Madrid quadrangle, Santa $\mathrm{Fe}$ and Sandoval Counties, New Mexico: U.S. Geological Survey Geologic Quadrangle Map GQ-1268, scale 1:62,500.

Bachman, G. O., and Harbour, R. L., 1970, Geologic map of the northern part of the San Andres Mountains, central New Mexico: U.S. Geological Survey Miscellaneous Geologic Investigations Map I-600, scale $1: 62,500$.

Bachman, G. O., and Myers, D. A., 1963, Geology of the Bear Peak NE Quadrangle, Doña Ana County, New Mexico: U.S. Geological Survey Miscellaneous Investigations Map I-374, scale $1: 31,680$.

1969, Geology of the Bear Peak area, Doña Ana County, New Mexico: U.S. Geological Survey Bulletin 1271-C, 46 p.

Balk, Robert, 1962, Geologic map of Tres Hermanas Mountains: New Mexico Bureau of Mines and Mineral Resources Geologic Map 16, scale $1: 48,000$.

Bedinger, M. S., Sargent, K. A., and Reed, J. E., 1984, Geologic and hydrologic characterization and evaluation of the Basin and Range province relative to the disposal of high-level radioactive waste, Part I--Introduction and guidelines: U.S. Geological Survey Circular 904-A [in press].

Bowring, S. A., Kent, S. C., and Sumner, Ward, 1983, Geology and $\mathrm{U}-\mathrm{Pb}$ geochronology of Proterozoic rocks in the vicinity of Socorro, New Mexico, in Chapin, C. E., and Callender, J. F., eds., Socorro region II: New Mexico Geological Society 34 th Field Conference Guidebook, p. 137-142.

Brookins, D. G., 1974, Preliminary radiometric age determination from the Florida Mountains, New Mexico: El Paso Geological Society Field Trip Guidebook 8, p. 47-55. 1982, Radiometric ages of Precambrian rocks from central New Mexico, in Callender, J. F., Grambling, J. A., and Wells, S. C., eds., Albuquerque country II: New Mexico Geological Society 33rd Field Conference Guidebook, p. 187-189.

Brookins, D. G., Bolton, W. R., and Condie, K. C., 1980, Rb-Sr isochron ages of four Precambrian igneous rock units from south-central New Mexico: Isochron/West, no. 29, p. 31-38. 
Brookins, D. G., and Majumdar, Arun, 1982, The Sandia granite-single or multiple plutons(?), in Callender, J. F., Grambling, J. A., and Wells, S. C., eds., Albuquerque country II: New Mexico Geological society 33rd Field Conference Guidebook, p. 221-223.

Budding, A. J., 1964, Geologic outline of the Jicarilla Mountains, Lincoln County, New Mexico, in Ash, S. R., and Davis, L. V., eds., Guidebook of the Ruidoso country: New Mexico Geological Society 15th Field Conference, p. 82-86.

Budding, A. J., and Condie, K. C., 1975, Precambrian rocks of the Sierra Oscura and northern San Andres Mountains, in Seager, W. R., Clemons, R. E., and Callender, J. F., eds., Guidebook of the Las Cruces country: New Mexico Geological society 26th Field Conference, p. 89-93.

Butler, P. A., Jr., 1964, Magnetite from intrusives and associated contact deposits, Lincoln County, New Mexico: Socorro, New Mexico Institute of Mining and Technology, Master's thesis, $63 \mathrm{p}$.

Cavin, W. J., Connolly, J. R., Woodward, L. A., Edwards, D. L., and Parchman, Mark, 1982, Precambrian stratigraphy of Manzanita and north Manzano Mountains, New Mexico, in Callender, J. F., Grambling, J. A., and Wells, S. C., eds., Albuquerque country II: New Mexico Geological Society 33rd Field Conference Guidebook, p. 191-196.

Clemons, R. E., 1976, Geology of east half Corralitos Ranch Quadrangle, New Mexico: New Mexico Bureau of Mines and Mineral Resources Geologic Map 36, scale 1:24,000, 2 sheets.

1982a, Geology of Florida Gap Quadrangle, Luna County, New Mexico: New Mexico Bureau of Mines and Mineral Resources Geologic Map 52, scale 1:24,000.

1982b, Geology of Massacre Peak Quadrangle, Luna County, New Mexico: New Mexico Bureau of Mines and Mineral Resources Geologic Map 51, scale 1:24,000.

Condie, K. C., 1976, Precambrian rocks of Ladron Mountains, Socorro County, New Mexico: New Mexico Bureau of Mines and Mineral Resources Geologic Map 38, scale 1:24.000.

1981, Precambrian rocks of southwestern United states and adjacent areas of Mexico: New Mexico Bureau of Mines and Mineral Resources Resource Map 13, scale 1:1,500,000,

2 sheets.

Condie, K. C., and Budding, A. J., 1979, Geology and geochemistry of Precambrian rocks, central and south-central New Mexico: New Mexico Bureau of Mines and Mineral Resources Memoir 35, $58 \mathrm{p}$.

Corbitt, L. L., 1971, structure and stratigraphy of the Florida Mountains, New Mexico: Albuquerque, University of New Mexico, Ph.D. dissertation, $115 \mathrm{p}$.

Cserna, E. G., 1956, structural geology and stratigraphy of the Fra Cristobal Quadrangle, sierra County, New Mexico: New York, Columbia University, Ph.D. dissertation, 119 p.

Cunningham, J. E., 1974, Geologic map and sections of Silver City Quadrangle, New Mexico: New Mexico Bureau of Mines and Mineral Resources Geologic Map 30, scale 1:24,000. 
Dane, C. H., and Bachman, G. O., 1961, Preliminary geologic map of the southwestern part of New Mexico: U.S. Geological Survey Miscellaneous Geologic Investigations Map I-344, scale $1: 380,160$.

1965, Geologic map of New Mexico: U.S. Geological Survey Map scale 1:500,000, 2 sheets.

Darton, N. H., 1917, Deming, New Mexico, folio 207 of Geologic atlas of the United States: U.S. Geological Survey, $15 \mathrm{p}$.

Disbrow, A. E., and Stoll, W. C., 1957, Geology of the Cerrillos area, Santa Fe County, New Mexico: New Mexico Bureau of Mines and Mineral Resources Bulletin 48, $73 \mathrm{p}$.

Doraibabu, Peethambarum, and Proctor, P. D., 1973, Trace base metals, petrography, and alteration of the Tres Hermanas stock, Luna County, New Mexico: New Mexico Bureau of Mines and Mineral Resources Circular 132, 29 p.

Dorman, J. H., 1951, structure of the Priest Granite, Manzano Mountains, New Mexico: Evanston, Illinois, Northwestern University, Master's thesis, $46 \mathrm{p}$.

Drewes, Harald, and Thorman, C. H., 1980a, Geologic map of the Cotton City Quadrangle and the adjacent part of the vanar Quadrangle, Hidalgo County, New Mexico: U.S. Geological Survey Miscellaneous Investigations Series Map I-1221, scale $1: 24,000$.

1980b, Geologic map of the steins quadrangle and the adjacent part of the Vanar Quadrangle, Hidalgo County, New Mexico: U.S. Geological Survey Miscellaneous Investigations Series Map I-1220, scale 1:24,000.

Dunham, K. C., 1935, Geology of the organ Mountains: New Mexico Bureau of Mines and Mineral Resources Bulletin 11, $272 \mathrm{p}$. Elston, W. E., 1957, Geology and mineral resources of Dwyer Quadrangle, Grant, Luna, and Sierra Counties, New Mexico: New Mexico Bureau of Mines and Mineral Resources Bulletin 38, $86 \mathrm{p}$.

Finnell, T. L., 1976a, Geologic map of the Reading Mountain Quadrangle, Grant County, New Mexico: U.S. Geological survey Miscellaneous Field Studies Map MF-800, scale 1:24,000. 1976b, Geologic map of the Twin Sisters Quadrangle, Grant County, New Mexico: U.S. Geological Survey Miscellaneous Field Studies Map MF-779, scale, 1:24,000.

1982, Geologic map of the Dorsey Ranch Quadrangle, Grant County, New Mexico: U.S. Geological Survey Miscellaneous Field Studies Map MF-1431, scale 1:24,000.

Flege, R. F., 1959, Geology of Lordsburg Quadrangle, Hidalgo County, New Mexico: New Mexico Bureau of Mines and Mineral Resources Bulletin $62,36 \mathrm{p}$.

Gillerman, Elliot, 1964, Mineral deposits of western Grant County, New Mexico: New Mexico Bureau of Mines and Mineral Resources Bulletin 83, $213 \mathrm{p}$. 
Gonzales, R. A., and Woodward, L. A., 1972, Petrology and structure of Precambrian rocks of the Pedernal Hills, New Mexico, in Kelley, V. C., and Trauger, F. D., eds., Guidebook of east-central New Mexico: New Mexico Geological Society 23rd Field Conference, p. 144-147.

Griswold, G. B., 1961; Mineral resources of Luna County, New Mexico: New Mexico Bureau of Mines and Mineral Resources Bulletin $72,157 \mathrm{p}$.

Hedlund, D. C., 1977, Geologic map of the Hillsboro and San Lorenzo Quadrangles, Sierra and Grant Counties, New Mexico: U.S. Geological Survey Miscellaneous Field studies Map MF-900-A, scale $1: 48,000,2$ sheets.

1978a, Geologic map of the Burro Peak Quadrangle, Grant County, New Mexico: U.S. Geological survey Miscellaneous Field studies Map MF-1040, scale 1:24,000.

1978b, Geologic map of the Tyrone quadrangle, Grant County, New Mexico: U.S. Geological Survey Miscellaneous Field Studies Map MF-1037, scale 1:24,000.

1978c, Geologic map of the Werney Hill Quadrangle, Grant County, New Mexico: U.S. Geological Survey Miscellaneous Field Studies Map MF-1038, scale 1:24,000.

1978d, Geologic map of the White signal Quadrangle, Grant County, New Mexico: U.S. Geological Survey Miscellaneous Field Studies Map MF-1041, scale 1:24,000.

1978e, Geologic map of the Wind Mountain Quadrangle, Grant County, New Mexico: U.S. Geological Survey Miscellaneous Field Studies Map MF-1031, scale 1:24,000.

1978f, Geologic map of the C Bar Ranch Quadrangle, Grant County, New Mexico: U.S. Geological Survey Miscellaneous Field studies Map MF-1039, scale 1:24,000.

1978g, Geologic map of the Gold Hill quadrangle, Hidalgo and Grant Counties, New Mexico: U.S. Geological Survey Miscellaneous Field studies Map MF-1035, scale 1:24,000. 1978h, Geologic map of the Ninetysix Ranch Quadrangle, Grant County, New Mexico: U.S. Geological Survey Miscellaneous Field studies Map MF-1034, scale 1:24,000.

1978i, Geologic map of the Soldiers Farewell Hill quadrangle, Grant County, New Mexico: U.S. Geological survey Miscellaneous Field Studies Map MF-1033, scale 1:24,000. 1980a, Geologic map of the Redrock NE Quadrangle, Grant County, New Mexico: U.S. Geological Survey Miscellaneous Field Studies Map MF-1264, scale 1:24,000.

1980b, Geologic map of the Redrock SE Quadrangle, Grant and Hidalgo Counties, New Mexico: U.S. Geological Survey Miscellaneous Field studies Map MF-1265, scale 1:24,000.

Herber, L. J., 1963, Precambrian rocks of La Joyita Hills, in Kuellmer, F. J., ed., Guidebook of the socorro region, New Mexico: New Mexico Geological society 14th Field Conference, p. 180-184.

Hernon, R. M., Jones, W. R., and Moore, S. L., 1964, Geology of the Santa Rita quadrangle, New Mexico: U.S. Geological Survey Geologic quadrangle Map GQ-306, scale 1:24,000. 
Hewitt, C. H., 1959, Geology and mineral deposits of the northern Big Burro Mountains-Redrock area, Grant County, New Mexico: New Mexico Bureau of Mines and Mineral Resources Bulletin 60, $151 \mathrm{p}$.

Hoffer, J. M., 1976, Geology of Portillo basalt field, southcentral New Mexico: New Mexico Bureau of Mines and Mineral Resources Circular 149, 30 p.

Jacobs, R. C., 1956, Geology of the central front of the Fra Cristobal Mountains, Sierra County, New Mexico:

Albuquerque, University of New Mexico, Master's thesis, $45 \mathrm{p}$.

Jahns, R. H., 1955, Geology of the Sierra Cuchillo, New Mexico, in Guidebook of south-central New Mexico: New Mexico GeoIogical Society Sixth Field Conference, p. 159-174.

Jicha, H. L., Jr., 1954, Geology and mineral deposits of Lake Valley Quadrangle, Grant, Luna, and Sierra Counties, New Mexico: New Mexico Bureau of Mines and Mineral Resources Bulletin $37,93 \mathrm{p}$.

Jones, W. R., Moore, S. L., and Pratt, W. P., 1970, Geologic map of the Fort Bayard Quadrangle, Grant County, New Mexico: U.S. Geological Survey Geologic Quadrangle Map GQ-865, scale $1: 24,000$.

Kelley, V. C., 1972, Geology of the Fort sumner sheet, New Mexico: New Mexico Bureau of Mines and Mineral Resources Bulletin 98, $55 \mathrm{p}$.

Kelley, V. C., and Northrop, S. A., 1975, Geology of Sandia Mountains and vicinity, New Mexico: New Mexico Bureau of Mines and Mineral Resources Memoir 29, $136 \mathrm{p}$.

Kelley, V. C., and Silver, Caswell, 1952, Geology of the Caballo Mountains, with special reference to regional stratigraphy and structure and to mineral resources, including oil and gas: Las Vegas, University of New Mexico Publications in Geology 4, $286 \mathrm{p}$.

Kelley, V. C., and Thompson, T. B., 1964, Tectonics and general geology of the Ruidoso-Carrizozo region, central New Mexico, in Ash, S. R., and Davis, L. V., eds., Guidebook of the Ruidoso country: New Mexico Geological Society 15 th Field Conference, p. 110-121.

Kottlowski, F. E., 1953, Geology and ore deposits of a part of the Hansonburg mining district, Socorro County, New Mexico: New Mexico Bureau Mines and Mineral Resources Circular 23, $9 \mathrm{p}$.

1960a, Reconnaissance geologic map of Las cruces thirtyminute Quadrangle: New Mexico Bureau of Mines and Mineral Resources Geologic Map 14, scale 1:126,720.

1960b, Summary of Pennsylvanian sections in southwestern New Mexico and southeastern Arizona: New Mexico Bureau of Mines and Mineral Resources Bulletin $66,187 \mathrm{p}$.

Kottlowski, F. E., Flower, R. H., Thompson, M. L., and Foster, R. W., 1956, stratigraphic studies of the San Andres Mountains, New Mexico: New Mexico Bureau of Mines and Mineral Resources Memoir 1, $132 \mathrm{p}$. 
Kuellmer, F. J., 1956, Geologic map of Hillsboro Peak thirtyminute Quadrangle, New Mexico: New Mexico Bureau of Mines and Mineral Resources Geologic Map 1, scale 1:126,720.

Lasky, S. G., 1947, Geology and ore deposits of the Little Hatchet Mountains, Hidalgo and Grant Counties, New Mexico: U. S. Geological Survey Professional Paper 208, 101 p.

Lopez, D. A., and Bornhorst, T. J., 1979, Geologic map of the Datil area, Catron County, New Mexico: U.S. Geological Survey Miscellaneous Investigations Series Map I-1098, scale $1: 50,000$.

Loring, A. K., and Loring, R. B., 1980, K-Ar ages of middle Tertiary igneous rocks from southern New Mexico: Isochron/ West, no. 28, p. 17-19.

Loughlin, G. F., and Koschmann, A. H., 1942, Geology and ore deposits of the Magadalena mining district, New Mexico: U.S. Geological Survey Professional Paper 200, 168 p.

McCleary, J. T., 1960, Geology of the northern part of the Fra Cristobal Range, Sierra and socorro Counties, New Mexico: Albuquerque, University of New Mexico, Master's thesis, $59 \mathrm{p}$.

McDowell, F. W., 1971, K-Ar ages of igneous rocks from the western United States: Isochron/West, v. 2, p. 12 .

Miller, J. P., Montgomery, Arthur, and Sutherland, P. K., 1963, Geology of part of the southern Sangre de Cristo Mountains, New Mexico: New Mexico Bureau of Mines and Mineral Resources Memoir 11, $106 \mathrm{p}$.

Millican, R. S., 1971, Geology and petrography of the Tertiary Riley-Cox pluton, Doña Ana County, New Mexico: El Paso, University of Texas, Master's thesis, $88 \mathrm{p}$.

Montgomery, Arthur, 1953, Precambrian geology of the Picuris Range, north-central New Mexico: New Mexico Bureau of Mines and Mineral Resources Bulletin 30, $89 \mathrm{p}$.

Morrison, R. B., 1965, Geologic map of the Duncan and Canador Peak Quadrangles, Arizona and New Mexico: U.S. Geological Survey Miscellaneous Geologic Investigations Map I-442, scale $1: 48,000$.

Mukhopadhyay, Bimal, Brookins, D. G., and Bolivar, S. L., 1975, $\mathrm{Rb}-\mathrm{Sr}$ whole-rock study of the Precambrian rocks of the Pedernal Hills, New Mexico: Earth and Planetary science Letters, v. 27, no. 2, p. 283-286.

Myers, D. A., 1977, Geologic map of the scholle quadrangle, Socorro, Valencia, and Torrance Counties, New Mexico: U.S. Geological Survey Geological quadrangle Map GQ-1412, scale $1: 24,000$.

Myers, D. A., and McKay, E. J., 1970, Geologic map of the Mount Washington Quadrangle, Bernalillo and Valencia Counties, New Mexico: U.S. Geological survey Geologic quadrangle Map GQ-886, scale $1: 24,000$.

1971, Geologic map of the Bosque Peak Quadrangle, Torrance, Valencia, and Bernalillo Counties, New Mexico: U.S. Geological Survey Geologic Quadrangle Map GQ-948, scale $1: 24,000$. 
1972, Geologic map of the Capilla Peak Quadrangle, Torrance and Valencia Counties, New Mexico: U.S. Geological Survey Geologic Quadrangle Map GQ-1008, scale 1:24,000.

1974, Geologic map of the southwest quarter of the Torreon 15-minute Quadrangle, Torrance and Valencia Counties, New Mexico: U.S. Geological Survey Miscellaneous Investigations Series Map I-820, scale $1: 24,000$.

1976, Geologic map of the north end of the Manzano Mountains, Tijeras and Sedillo Quadrangles, Bernalillo County, New Mexico: U.S. Geological Survey Miscellaneous Investigations Series Map I-968, scale 1:24,000.

Myers, D. A., McKay, E. J., and Sharps, J. A., 1981, Geologic map of the Becker Quadrangle, Valencia and Socorro Counties, New Mexico: U.S. Geological survey Geologic Quadrangle Map GQ-1556, scale 1:24,000.

Myers, D. A., Sharps, J. A., and McKay, E. J., 1984, Geologic map of the Becker SW and Cerro Montoso Quadrangles, Socorro County, New Mexico: U.S. Geological Survey Miscellaneous Investigations Series Map I-1567, scale 1:24,000 [in press].

New Mexico Geological Society, 1982, New Mexico highway geologic map: scale $1: 1,000,000$.

Perhac, R. M., 1970, Geology and mineral deposits of the Gallinas Mountains, Lincoln and Torrance Counties, New Mexico: New Mexico Bureau of Mines and Mineral Resources Bulletin 95, $51 \mathrm{p}$.

Pratt, w. C., 1967, Geology of the Hurley West Quadrangle, Grant County, New Mexico: U.S. Geological Survey Bulletin 1241-E, p. E1-E91.

Pratt, W. C., and Jones, W. R., 1965, The Cameron Creek laccolith--A trap-door intrusion near silver City, New Mexico, in Fitzsimmons, J. P., and Lochman-Balk, Christina, eds., Guidebook of southwestern New Mexico: New Mexico Geological Society 16th Field Conference, p. 158-163.

Rawson, D. E., 1957, The geology of the Tecolote Hills area, Lincoln County, New Mexico: Albuquerque, University of New Mexico, Master's thesis, $77 \mathrm{p}$.

Register, M. E., and Brookins, D. G., 1979, Geochronologic and rare-earth study of the Embudo granite and related rocks, in Ingersoll, R. V., Woodward, L. A. and James, H. L., eds., Guidebook of Santa Fe country: New Mexico Geological Society 30th Field Conference, p. 155-158.

Reiche, Parry, 1949, Geology of the Manzanita and north Manzano Mountains, New Mexico: Geological Society of America Bulletin, v. 60, no. 7, p. 1183-1212.

Sargent, K. A., and Bedinger, M. S., 1984, Geologic and hydrolgic characterization and evaluation of the Basin and Range province relative to the disposal of high-level radioactive waste, Part II--Geologic and hydrologic characterization: U.S. Geological Survey Circular 904-B [in press].

Schmidt, P. G., and Craddock, Campbell, 1964, The geology of the Jarilla Mountains, Otero County, New Mexico: New Mexico Bureau of Mines and Mineral Resources Bulletin 82, 55 p. 
Seager, W. R., 1981, Geology of Organ Mountains and southern San Andres Mountains, New Mexico: New Mexico Bureau of Mines and Mineral Resources Memoir 36, $97 \mathrm{p}$.

Seager, W. R., and Clemons, R. E., 1975, Middle to Late Tertiary geology of Cedar Hills-Selden Hills area, New Mexico: New Mexico Bureau of Mines and Mineral Resources Circular 133, $24 \mathrm{p}$.

Seager, W. R., Hawley, J. W., and Clemons, R. E., 1971, Geology of San Diego Mountain area, Doña Ana County: New Mexico Bureau of Mines and Mineral Resources Bulletin 97, $38 \mathrm{p}$. Seager, W. R., Kottlowski, F. E., and Hawley, J. W., 1976, Geology of Doña Ana Mountains, New Mexico: New Mexico Bureau of Mines and Mineral Resources Circular 147, $36 \mathrm{p}$.

Smith, C. T., and Budding, A. J., 1959, Reconnaissance geologic map of Little Black Peak fifteen-minute Quadrangle, east half: New Mexico Bureau of Mines and Mineral Resources Geologic Map 11, scale 1:62,500.

Soule, J. M., 1972, structural geology of the northern part of Animas Mountains, Hidalgo County, New Mexico: New Mexico Bureau of Mines and Mineral Resources Circular 125, $15 \mathrm{p}$. staatz, M. H., Adams, J. H., and Conklin, N. M., 1965, Thoriumbearing microcline-rich rocks in the southern Caballo Mountains, Sierra County, New Mexico: U.S. Geological survey Professional Paper 525-D, p. D48-D51.

staatz, M. H., and Norton, J. J., 1942, The Precambrian geology of the Los Piños Range, New Mexico: Evanston, Illinois, Northwestern University, Master's thesis, $150 \mathrm{p}$.

stark, J. T., 1956, Geology of the southern Manzano Mountains, New Mexico: New Mexico Bureau of Mines and Mineral Resources Bulletin 34, $49 \mathrm{p}$.

Stark, J. T., and Dapples, E. C., 1946, Geology of the Los Piños Mountains, New Mexico: Geological Society of America Bulletin, v. 57, pt. 1, p. 1121-1172.

stearns, C. E., 1953, Tertiary geology of the Galisteo-Tonque area, New Mexico: Geological Society of America Bulletin, v. 64, no. 4, p. 459-507.

steiger, R. H., and Wasserburg, G. J., 1966, systematics in the $\mathrm{Pb}-208-\mathrm{Th}-232, \mathrm{~Pb}-207-\mathrm{U}-235$, and $\mathrm{Pb}-206-\mathrm{U}-238$ systems: Journal Geophysical Research, v. 71, p. 6065-6090.

Streckeisen, A. L., 1976, To each plutonic rock its proper name: Earth science Reviews, v. 12, p. 1-33.

sun, Ming-Shan, and Baldwin, Brewster, 1958, Volcanic rocks of the Cienega area, Santa Fe County, New Mexico: New Mexico Bureau of Mines and Mineral Resources Bulletin 54, $80 \mathrm{p}$.

Taggert, J. E., and Brookins, D. G., 1975, Rb-Sr whole-rock age determinations for Sandia Granite and Cibola Gneiss, New Mexico: Isochron/West, no. 12 , p. 5-8.

Thompson, T. B., 1973, Mineral deposits of Nogal and Bonito mining districts, New Mexico: New Mexico Bureau of Mines and Mineral Resources Circular 123, 29 p. 
Thorman, C. H., and Drewes, Harald, 1978, Geologic map of the Gary and Lordsburg Quadrangles, Hidalgo County, New Mexico: U.S. Geological Survey Miscellaneous Investigations Series Map I-1151, scale $1: 24,000$.

Titley, S. R., 1959, Geological summary of the Magdalena mining district, Socorro County, New Mexico, in Weir, J. E., Jr., and Baltz, E. H., eds., Guidebook of west-central New Mexico: New Mexico Geological Society 10th Field Conference, p. 144-148.

Tonking, W. H., 1957, Geology of Puertecito Quadrangle, Socorro County, New Mexico: New Mexico Bureau of Mines and Mineral Resources Bulletin 41, $67 \mathrm{p}$.

Trauger, F. D., 1972, Water resources and general geology of Grant County, New Mexico: New Mexico Bureau of Mines and Mineral Resources Hydrologic Report 2, 211 p.

Warner, L. A., Holser, W. T., Wilmarth, V. R., and Cameron, E. N., 1959, Occurrence of non-pegmatite beryllium in the United States: U.S. Geological survey Professional Paper $318,198 \mathrm{p}$.

Weber, R. H., 1964, Geology of the Carrizozo Quadrangle, New Mexico, in Ash, S. F., and Davis, L. V., eds., Guidebook of the Ruidoso country: New Mexico Geological Society 15th Field Conference, p. 100-109.

White, D. L., 1978, Rb-Sr isochron ages of some Precambrian plutons in south-central New Mexico: Isochron/West, no. 12, p. 8-14.

Willard, M. E., and Givens, D. B., 1958, Reconnaissance geologic map of Datil thirty-minute Quadrangle: New Mexico Bureau of Mines and Mineral Resources Geologic Map 5, scale 1:126,720.

Wilpolt, R. H., and Wanek, A. A., 1951, Geology of the region from Socorro and San Antonio east to Chupadera Mesa, Socorro County, New Mexico: U.S. Geological survey Oil and Gas Investigations Map OM-121, scale 1:63,360, 2 sheets.

Woodward, L. A., 1970, Precambrian rocks of southwestern New Mexico, in Woodward, L. A., ed., Tyrone-Big Hatchet Mountains-Florida Mountains region, New Mexico: New Mexico Geological Society 21st Field Conference Guidebook, p. 27-31.

Wrucke, C. T., and Bromfield, C. S., 1961, Reconnaissance geologic map of part of the southern Peloncillo Mountains, Hidalgo County, New Mexico: U.S. Geological Survey Mineral Investigations Field studies Map MF-160, scale 1:62,500, 2 sheets.

Zeller, R. A., Jr., 1958, Reconnaissance geologic map of Playas fifteen-minute Quadrangle: New Mexico Bureau of Mines and Mineral Resources Geologic Map 7, scale 1:62,500. 1962, Reconnaissance geologic map of southern Animas Mountains: New Mexico Bureau of Mines and Mineral Resources Geologic Map 17, scale 1:62,500. 1965, Stratigraphy of the Big Hatchet Mountains area, New Mexico: New Mexico Bureau of Mines and Mineral Resources Memoir $16,128 \mathrm{p}$. 
1970, Geology of Little Hatchet Mountains, Hidalgo and Grant Counties, New Mexico: New Mexico Bureau of Mines and Mineral Resources Bulletin 96, 26 p. 1975, Structural geology of Big Hatchet Peak Quadrangle, Hidalgo County, New Mexico: New Mexico Bureau of Mines and Mineral Resources Circular 146, $23 \mathrm{p}$.

Zeller, R. A., Jr., and Alper, A. M., 1965, Geology of the walnut Wells Quadrangle, Hidalgo County, New Mexico: New Mexico Bureau of Mines and Mineral Resources Bulletin 84, 105 p. 